\title{
The effect of an educational program for pregnant women to prevent allergic diseases in infants: study protocol for a randomized controlled trial
}

\author{
Rie Nakamura ${ }^{1 *}$, Nao Ishiguro², Eiji Naru', Yukiko Ishitsuka', Masato Nakade ${ }^{1}$ and Yoko Nezu²
}

\begin{abstract}
Background: Allergic diseases in infants have dramatically increased in developed countries during the past few decades. To date, extensive research has been done on risk factors for allergies in infancy, and preventive measures against them. However, the effect of the primary approach to preventing infantile allergy is still limited. The aim of this trial is to evaluate whether prenatal education interventions, including the latest public research results on allergic diseases, prevent the onset of infant allergies.

Methods/design: We designed a randomized controlled, two-arm (standard prenatal education vs our education), parallel-group, assessor-blind trial. A sample of 120 pregnant women will be recruited at Chiba Aiyu-kai Kinen Hospital and allocation is by computer-generated randomization.

Pregnant women in the intervention arm participate in the childbirth education program established by the specialist and a pediatric allergy educator. The program was developed based on evidences supporting interventions on primary prevention, which are suggested to be beneficial to infantile allergies in recent studies. The primary objective of the study is to determine whether it is possible to establish effective behaviors for allergy prevention in early infancy in the children of pregnant women who participate in an educational program developed by pediatric allergy specialists. Four months after birth, their behaviors will be compared against those of pregnant women who did not participate in the program.
\end{abstract}

Discussion: Allergies are common in many individuals worldwide, and can be present from babyhood through the person's lifetime. One of the strong points of this study is that it should provide pregnant women with accumulated information on preventive knowledge against allergy, that can be effective in some cases, and that women can apply a combination of these behaviors before and after pregnancy. The results of our program will be publicized to help change the behaviors of mothers, and, if the program is effective, for preventing allergies in infants, it will be disclosed worldwide as a new preventive strategy for allergy in infants.

Trial registration: UMIN-CTR, ID: UMIN000034730 Retrospectively registered on 1 December 2018.

Keywords: Allergies, Infant allergy, Prenatal, Pregnancy education, Allergic march, Educational intervention, Food allergy

\footnotetext{
* Correspondence: r-itou@kose.co.jp

${ }^{1}$ KOSÉ Corporation Research Laboratories, 48-18 Sakae-cho, Kita-ku, Tokyo

114-0005, Japan

Full list of author information is available at the end of the article
}

(c) The Author(s). 2019 Open Access This article is distributed under the terms of the Creative Commons Attribution 4.0 International License (http://creativecommons.org/licenses/by/4.0/), which permits unrestricted use, distribution, and reproduction in any medium, provided you give appropriate credit to the original author(s) and the source, provide a link to the Creative Commons license, and indicate if changes were made. The Creative Commons Public Domain Dedication waiver (http://creativecommons.org/publicdomain/zero/1.0/) applies to the data made available in this article, unless otherwise stated. 


\section{Introduction}

In Japan, as in most developed countries, the prevalence of allergy, including atopic dermatitis (AD), food allergy (FA), asthma, and allergic rhinitis, among infants has increased in recent years and is a serious health problem [1]. The "allergic march," which was first proposed by Minoru Baba, and refers to the chain reaction of allergies in people predisposed to atopic dermatitis [2, 3], has attracted a great deal of attention in recent years, and it has been suggested that preventative measures during the neonatal and early infancy period could be effective against this condition.

To date, extensive research has been conducted on the risk factors for, and preventative measures against, allergy during infancy. In addition, evidence supporting the efficacy of several of these preventative measures has accumulated. For example, in 2008, Lack hypothesized that sensitization to allergens occurs through environmental exposure to allergens through the skin and that consumption of food allergens induces oral tolerance (dual-allergenexposure hypothesis [4, 5]), and proposed a new allergy-prevention strategy based on the maintenance of skin-barrier function. To verify the dualallergen-exposure hypothesis, randomized clinical trials (RCTs) of the effects of a moisturizer were conducted, and its efficacy in AD patients was demonstrated [6-8]. Lowe et al. (2016) [9] performed a meta-analysis and showed that a moisturizer can statistically significantly prevent infantile AD when used in the neonatal period, and that the onset of $\mathrm{AD}$ is associated with sensitization to egg-white antigen. On the other hand, this analysis suggested that the efficacy of moisturizer alone used from the neonatal period is poor because it cannot prevent sensitization to food allergens.

In addition to the dual-allergen-exposure hypothesis, some studies suggest that maternal intestinal bacterial flora is associated with neonatal allergy [10, 11]. Currently, probiotics [12], prebiotics [13], and synbiotics [14] are effective for the treatment of abnormal intestinal bacterial flora. Some RCTs have examined the effects of probiotic intake by pregnant and lactating women on preventing the development of allergies in infants [15-19]. Zuccotti et al. (2015) $[20,21]$ performed a meta-analysis on these RCTs, and suggested that probiotic intake in pregnant and lactating women can reduce the incidence of rashes in neonates. However, probiotics did not reduce the prevalence of asthma or allergic rhinitis. A different meta-analysis of RCTs assessing the effects of prebiotics [22] and synbiotics [23] showed that although these organisms prevent the development of a rash, they have no protective effects against allergic sensitization in neonates. Additional studies are needed to assess the differences in intestinal bacterial flora between various races or regions.

Some observational studies identified many risk factors and preventive measures for allergy in infants. An observational study that examined the association between living conditions and infantile asthma [24, 25] reported that the combination of preventive measures to avoid allergens, such as tick and mold, can reduce the risk of allergy. Secondhand tobacco smoke from parents or other family members living together increases the risk of bronchial asthma in infants [26-28]. The association between living conditions and the risk of allergy in infants has been researched extensively. Many observational studies examined the correlation between food intake by pregnant women or lactating mothers and the development of allergies in infants. Specifically, the intake of vitamin D (VD) [29-31] and n-3 polyunsaturated fatty acids [32-34] during pregnancy reduces the risk of allergy in infants. However, there are no recent meta-analyses [35-40] or RCTs [41-46] demonstrating the efficacy of these nutrients against allergies.

The preventive measures reported to date have shown limited effects, and a clear and effective method to prevent allergies in infants remains to be identified. Because multiple risk factors are associated with allergies in infants, the preventive measures identified to date are not effective.

We hypothesized that providing pregnant women with knowledge regarding the latest research findings on allergy prevention in prenatal and postnatal period may increase awareness and knowledge and, thereby lead to changes in behavior to prevent allergy in infants. The aim of this trial is, therefore, to evaluate whether prenatal education interventions, including the latest public research results on allergic diseases, prevent the onset of infant allergies.

This protocol has been written in accordance with the Standard Protocol Items: Recommendations for Interventional Trials (SPIRIT) guideline (Additional file 1). This report is based on protocol version 9, approved 1 March 2019, by Chiba Aiyu-kai Kinen Hospital Ethics Committee.

\section{Methods/design \\ Objectives \\ Primary objective}

The primary objective of the study is to determine whether it is possible to establish effective behaviors for allergy prevention during early infancy in pregnant women who participate in an educational 
program developed by pediatric allergy specialists. Four months after birth, their behaviors will be compared against those of pregnant women who did not participate in the program.

\section{Secondary objectives}

The secondary objectives are as follows:

- To determine whether the use of a moisturizer can reduce the onset of $\mathrm{AD}$ and eczema

- To determine whether the onset of other atopic disorders can be prevented by the use of a moisturizer

- To examine the association between the onset of $\mathrm{AD}$ and food allergy sensitization

- To establish the safety of the recommended moisturizer in neonates

- To investigate the presence of allergies, skin condition, serum immunoglobulin E (IgE), and thymus and activation-regulated chemokine (TARC) levels in neonates

\section{Trial design}

This study is an assessor-blinded, randomized controlled, parallel-group comparison study (comparing our educational program group with an established childbirth education group) conducted in Chiba Aiyukai Kinen Hospital (hereafter referred to as "our hospital") to examine the superiority of the educational program over established programs. Subjects are randomized in a 1:1 ratio into one of the two groups. The participants and study personnel are not blinded with respect to the assignments.

This protocol is written in accordance with the Standard Protocol Item: Recommendations for Interventional Trials (SPIRIT) guideline. Trial registration is through the University Hospital Medical Information Network - Clinical Trials Registry (UMIN-CTR) (UMIN000034730).

\section{Participants}

\section{Recruitment procedure}

Participants are recruited among all pregnant women who visit our hospital for consultation regarding delivery. The investigator meets with each pregnant woman to provide oral and written information on the study and to request participation. Participants are selected according to the eligibility criteria. The pregnant women discuss participation with their respective families, and those who agree to participate in the study provide informed consent. After the collection of consent forms, the participants are randomized to one of two groups.

\section{Eligibility criteria}

Eligibility and exclusion criteria are as follows:

Eligibility criteria (individuals must meet two criteria):

- Those planning to give birth in our hospital

- Those planning to attend the childbirth education program provided by our hospital

Exclusion criteria (any of the following criteria):

- Those who were not planning to give birth in our hospital

- Birth of triplets or more

- Children with serious congenital malformations

- Abnormal birth including fetal distress and neonatal asphyxia

- Other pregnant women and neonates assessed as inadequate for the study by a physician

\section{Intervention}

\section{Intervention arm}

Pregnant women in the intervention arm participate in the childbirth education program established by the specialist and a pediatric allergy educator (PAE). The program was developed based on evidences supporting interventions on primary prevention, which are suggested to be beneficial to infant's allergies in recent studies. In addition, the intervention groups will receive this program in face-to-face education. In this program, we propose three types of barriers that protect infants from allergy: the intestinal mucosa, the respiratory tract mucosa, and the skin. We then recommend behaviors for mothers that improve the functions of these three types of barriers. Table 1 explains the details of the program using the Template for Intervention Description and Replication (TIDieR) [48], a template for intervention description.

\section{Control arm}

A leaflet summarizing the content of the educational program that is provided to the intervention arm is made available to subjects in the control arm at approximately 20 and 30 weeks of pregnancy.

\section{Measurements/assessments \\ Primary outcomes}

Self-evaluation of questionnaire to identify the behavioral characteristics of mothers based on the educational program at 4 months after delivery Primary outcomes are evaluated according to a selfevaluation score at 4 months after delivery in both arms.

The score is determined using a survey sheet created for this study (Appendix) to assess the behavioral 
Table 1 Details of the educational program provided to the intervention arm

\begin{tabular}{|c|c|}
\hline Item & Description \\
\hline 1. Brief name & Perinatal education to prevent allergy in infants \\
\hline 2. Why? & $\begin{array}{l}\text { Although many parents are anxious regarding allergies and skin conditions in infants [47], } \\
\text { there are few opportunities to learn about the prevention of pediatric allergies and skin conditions. } \\
\text { Extensive information on pediatric allergy is available based on scientific evidence, and prophylaxis } \\
\text { in pregnant women is expected to be effective to prevent allergy in infants. } \\
\text { If pregnant women learn how to prevent pediatric allergy based on scientific evidence } \\
\text { and apply these principles to childcare, this can promote the establishment of a prophylactic } \\
\text { strategy against allergy in infants }\end{array}$ \\
\hline 3. What materials? & $\begin{array}{l}\text { Educational materials for the program were prepared using PowerPoint. A handbook with } \\
\text { illustrations and photographs reviewed by a specialist is provided to mothers to educate } \\
\text { them about proper skin care for infants and the optimal diet during pregnancy and lactation }\end{array}$ \\
\hline 4. What procedures? & $\begin{array}{l}\text { A session planned during early and late pregnancy consists of the following: } \\
>\text { Program in Early pregnancy } \\
\text { Title: What you can do for your baby } \\
\text { Subtitle: Advice from pediatric allergy specialists } \\
\text { Intestinal mucosa } \\
\checkmark \text { Effect of the maternal intestinal bacterial flora on the fetus } \\
\checkmark \text { A diet that includes nutrients (oligosaccharides, dietary fiber, and fermented food) is ideal for } \\
\text { pregnant women to regulate for healthy intestinal bacterial flora } \\
\checkmark \text { Effect of vitamin D and a diet that includes vitamin D } \\
\checkmark \text { Effect of n-3 polyunsaturated fatty acids and a diet that includes this acid } \\
\text { Skin } \\
\checkmark \text { Association between the skin of infants and sensitization to allergens } \\
\checkmark \text { Adequate exposure to ultraviolet light } \\
\text { Respiratory tract mucosa } \\
\checkmark \text { Effect of smoking on pediatric bronchial asthma } \\
>\text { Program in Late pregnancy } \\
\text { Title: What you want to know for your baby? } \\
\text { Subtitle: Advice from specialists on pediatric allergy: "Three barriers protecting our body" } \\
\text { Intestinal mucosa } \\
\text { (the same content as in Program in Early pregnancy) } \\
\text { Skin } \\
\checkmark \text { Association between the skin of infants and sensitization to allergens } \\
\checkmark \text { Differences between the skin of infants and that of adults } \\
\checkmark \text { Prevention of allergic dermatitis and proper skin care starting at the neonatal period } \\
\checkmark \text { Proper skin care for neonates (how to wash and moisturize the skin) } \\
\checkmark \text { Proper exposure to air } \\
\text { Respiratory tract mucosa } \\
\checkmark \text { Effect of smoking on pediatric bronchial asthma } \\
\checkmark \text { Risk of exposure of infants to allergens in the living environment, in particular in bedclothes } \\
\checkmark \text { Cleaning bedclothes and the living areas of infants }\end{array}$ \\
\hline 5. Who provides? & Specialist or educator of pediatric allergy \\
\hline 6. How? & Face-to-face group learning \\
\hline 7. Where? & Chiba Aiyu-kai Kinen Hospital where pregnant women are planning to give birth \\
\hline 8. When? & Two 90-min sessions (at approximately 20 and 30 weeks of pregnancy) \\
\hline 9. Tailoring & Not individualized \\
\hline 10. Modifications & Any changes occurring during the study period need to be reported \\
\hline 11. How well? & $\begin{array}{l}\text { Plan: To promote adherence to the recommended skin care practices among subjects participating } \\
\text { in the educational program. A moisturizer is provided free of charge to those who want to use it }\end{array}$ \\
\hline 12. How well? & Practice: Strategies to promote adherence to skin care practices will be reported in a paper \\
\hline
\end{tabular}

characteristics of mothers. We prepared 21 questions to assess the dietary habits of mothers, living conditions, and the skin care of children based on the ideal behavior of mothers to prevent allergy in infant as proposed by specialists. Five options (a-e) are provided for all questions: $\mathrm{a}=1, \mathrm{~b}=2, \mathrm{c}=3, \mathrm{~d}=4$, and $\mathrm{e}=5$. Higher scores indicate more appropriate behaviors of mothers to prevent pediatric allergy at each time point.

\section{Secondary outcomes}

We set the following seven secondary outcomes:

1. Incidence and severity of atopic dermatitis and eczema infantile

The incidence and severity of $\mathrm{AD}$ and eczema in infants aged 1 week, 1 month, 4 months, and 12 months 
are determined by a "blinded" pediatrician according to the Clinical Practice Guidelines for the Management of Atopic Dermatitis 2016 prepared by the Japanese Dermatological Association: URL:https:// www.dermatol.or.jp/uploads/uploads/files/guideline/ato picdermatitis_guideline.pdf.

2. Incidence of food allergy and sensitization to egg white, milk, and ovomucoid

The incidence of food allergy in infants aged 4 and 12 months is determined by sensitization using serum antigen-specific IgE [49], medical interview, and oral food challenge or a clear history of allergy triggered by accidentally ingested foods

3. Analysis of stratum corneum hydration, transepidermal water loss (TEWL), and microscopic and digital images

Stratum corneum hydration in infants is measured three to five times on the left lower leg, forehead, and left cheek using Skicon-200EX ${ }^{\circ}$ (IBS Japan Co., Ltd., Shizuoka, Japan). TEWL is determined two to three times on the left lower leg, forehead, and left cheek using the VapoMeter ${ }^{\circ}$ (DelfinTechnologies, Kuopio, Finland). Enlarged images of the skin of the left lower leg, forehead, and left cheek in infants are acquired using a USB microscope M3 (Scalar Corporation, Tokyo, Japan). Images of a wide range of skin surfaces in infants are obtained using a digital camera (Canon, Tokyo, Japan). The skin is measured and photographed at $22^{\circ} \mathrm{C}$ and $50 \%$ humidity.

\section{TARC level}

Serum TARC level is measured in infants aged 4 and 12 months to assess the severity of $\mathrm{AD}$

\section{Frequency of use and amount of moisturizer}

The total amount of moisturizer used during the study is calculated to predict the effect of the educational program. The moisturizer is provided free of charge to those who want to use it

6. Questionnaire survey on living habits, awareness, and knowledge of mothers before and after pregnancy

A questionnaire survey on living habits, awareness, and knowledge of mothers before and after pregnancy was prepared. Subjects answer the self- evaluation questions in the survey at 30 weeks of pregnancy, and at 1, 4, and 12 months after delivery. Questions on living habits address stool frequency, use of supplements, eating habits between meals, and foods avoided or foods eaten. Regarding awareness and knowledge, the questions address what the mothers care about before and after pregnancy, how they intend to provide nourishment for the baby, and their concerns regarding childcare and the skin care of the baby.

\section{Adverse events}

Self-reported adverse events associated with the use of the moisturizer provided free of charge to those who want to use it during the study are recorded.

\section{Baseline characteristics}

The baseline characteristics are evaluated at approximately 20 weeks of pregnancy. The variables to be measured include age; delivery experience; history and type of allergy of the subject, their partner, and siblings; type of pet, if any; and smoking status of the subject and her family members living together.

\section{Participant timeline}

Table 2 shows the consent forms obtained from the subjects, the intervention, and the evaluation schedule.

\section{Sample size}

In this study, the number of deliveries per month at the investigational site was estimated at $15-20$, or more than approximately 200 childbirths per year. Moreover, with the current Japanese infant medical checkup system, it is unlikely that the mother will avoid the hospital in the first 4 months after delivery. Therefore, assuming a minimal recruitment rate of $70 \%$ and a less than $10 \%$ dropout rate, we expect a total of $120(200 \times 0.7 \times 0.9=126)$ participants in our study. A questionnaire aimed at identifying the behavioral characteristics of mothers was created for the study to assess primary outcomes. Currently, there are no data showing the effectiveness of the survey sheet. Considering the inclusion of 60 subjects per group with a significance level of 0.05 and a standard deviation of 16 under the conditions described above, the expected upper limit of the standard error of the mean was approximately eight using a $t$ test with a statistical power of $80 \%$. Based on this estimate, the final target sample size was set at 120 patients. The statistical power was calculated using $R$ ver.3.5.2 statistical software ( $\mathrm{R}$ Foundation for Statistical Computing, Vienna, Austria). 
Table 2 Consent, enrolment/allocation, and assessment of subjects (Additional file 2)

\begin{tabular}{|c|c|c|c|c|c|c|c|c|}
\hline \multirow[b]{3}{*}{ Time point } & \multicolumn{8}{|l|}{ Study period } \\
\hline & \multirow{2}{*}{$\begin{array}{l}\text { Enrollment } \\
\text { Allocation } \\
\text { Early } \\
\text { pregnancy }\end{array}$} & \multicolumn{7}{|c|}{ Post allocation } \\
\hline & & $\begin{array}{l}20 \text { weeks of } \\
\text { pregnancy }\end{array}$ & $\begin{array}{l}30 \text { weeks of } \\
\text { pregnancy }\end{array}$ & Delivery & Discharge & $\begin{array}{l}1 \text { month } \\
\text { after delivery }\end{array}$ & $\begin{array}{l}4 \text { months } \\
\text { after delivery }\end{array}$ & $\begin{array}{l}12 \text { months } \\
\text { after delivery }\end{array}$ \\
\hline \multicolumn{9}{|l|}{ Enrollment/allocation: } \\
\hline Inclusion & $\bullet$ & & & & & & & \\
\hline Obtaining informed consent & $\bullet$ & & & & & & & \\
\hline Randomization & $\bullet$ & & & & & & & \\
\hline Baseline survey & & $\bullet$ & & & & & & \\
\hline \multicolumn{9}{|l|}{ Interventions: } \\
\hline Educational program & & $\bullet$ & $\bullet$ & & & & & \\
\hline Established childbirth education & & $\bullet$ & $\bullet$ & & & & & \\
\hline \multicolumn{9}{|l|}{ Assessments: } \\
\hline $\begin{array}{l}\text { Questionnaire survey on } \\
\text { living habits, awareness, } \\
\text { and knowledge of mothers } \\
\text { before and after pregnancy }\end{array}$ & & & $\bullet$ & & & $\bullet$ & $\bullet$ & $\bullet$ \\
\hline $\begin{array}{l}\text { Survey on the behavioral } \\
\text { characteristics of mothers }\end{array}$ & & & & & & $\bullet$ & $\bullet$ & $\bullet$ \\
\hline Blood collection from mothers & $\bullet$ & & $\bullet$ & & & & & \\
\hline $\begin{array}{l}\text { Blood collection from infants } \\
\text { (lgE and TARC) }\end{array}$ & & & & & & & $\bullet$ & $\bullet$ \\
\hline $\begin{array}{l}\text { Stratum corneum hydration } \\
\text { of infants }\end{array}$ & & & & & $\bullet$ & $\bullet$ & $\bullet$ & \\
\hline TEWL of infants & & & & & $\bullet$ & $\bullet$ & $\bullet$ & \\
\hline $\begin{array}{l}\text { Findings on the skin of infants } \\
\text { (scoring atopic dermatitis } \\
\text { (SCORAD)) [50] }\end{array}$ & & & & & $\bullet$ & $\bullet$ & $\bullet$ & \\
\hline Images of the skin of infants & & & & & $\bullet$ & $\bullet$ & $\bullet$ & \\
\hline $\begin{array}{l}\text { Diagnosis of atopic dermatitis } \\
\text { in infants }\end{array}$ & & & & & & & $\bullet$ & $\bullet$ \\
\hline $\begin{array}{l}\text { Diagnosis of food allergy in } \\
\text { infants }\end{array}$ & & & & & & & $\bullet$ & $\bullet$ \\
\hline Provision of moisturizer & & & & & $\bullet$ & $\bullet$ & $\bullet$ & \\
\hline $\begin{array}{l}\text { Collection of the moisturizer } \\
\text { container }\end{array}$ & & & & & & $\bullet$ & $\bullet$ & $\bullet$ \\
\hline
\end{tabular}

Legend: IgE immunoglobulin E, SCORAD scoring atopic dermatitis, TARC thymus and activation-regulated chemokine, TEWL transdermal water loss

\section{Randomization procedure and concealment of allocation}

Participants who meet the eligibility criteria and agree to participate in the study are randomized after signing the informed consent form. These subjects are stratified according to the estimated delivery date into winter and other seasons, and randomized using the permuted-block method. A statistical analyst generates a random allocation code using $\mathrm{R}$ statistical software ( $\mathrm{R}$ Foundation for Statistical Computing) to randomize the subjects at each investigational site. The study is an assessor-blinded trial, and all raters are blinded with respect to the assignments. Also only the statistical analyst is aware of the stratification block size; the remaining staff is blinded. Subjects are randomized in a 1:1 ratio into one of two groups.

\section{Statistical analysis Full analysis set}

Subjects enrolled in the study who started any of the study procedures are included in the full analysis set (FAS). However, those with a confirmed serious deviation from the protocol and those determined ineligible for the study after enrollment are excluded from the FAS. 


\section{Intention-to-treat analysis}

In general, all statistical analyses are performed by the intention-to-treat principle.

\section{Primary outcomes}

Self-evaluation of questionnaire to identify the behavioral characteristics of mothers based on the educational program at 4 months after delivery

A linear mixed-effects model is used to analyze the total score of the questionnaire at 1, 4, and 12 months after delivery as an outcome variable. A mixed-effects model for repeated measurements (MMRM) [51] is used to properly handle missing values or dropouts that could arise during the study. An unstructured covariance structure is used to assess the correlation between outcomes at these time points. Mean changes from baseline are modeled as outcome variables for the MMRM. Mean changes from baseline at each time point are analyzed individually using a regression model. If the regression parameters cannot be estimated using the unstructured model, the covariance structure is changed in the following sequence: Toeplitz matrix model, heterogeneous compound symmetry model, autoregressive model (1), compound symmetry model, and variance components model. A primary analysis is performed using estimates for the regression parameter or regression parameter test at 4 months after delivery. The significance level is set at $5 \%$ (two-sided).

\section{Secondary outcomes \\ Incidence and severity of atopic dermatitis and eczema infantile}

The incidence of infantile $A D$ and eczema infantile is compared between groups at all time points using Pearson's chi-squared test. The severity of these diseases is compared between groups using descriptive statistics of scores at each time point. Subgroup analyses are performed to assess the incidence and severity of $\mathrm{AD}$ related to the amount and frequency of moisturizer used during the study and the skin condition of infants.

\section{Incidence of food allergy and sensitization to egg white, milk, and ovomucoid}

The rate of sensitization to each allergen is compared between groups with a cut-off value of the incidence of food allergy and the serum antigen-specific IgE level (equal to or more than class II) in infants at each time point using Pearson's chi-squared test. Subgroup analysis is performed to assess the outcomes related to the amount and frequency of moisturizer used during the study and the onset of $\mathrm{AD}$ in infants.
Analysis of stratum corneum hydration, TEWL, and microscopic and digital images

Descriptive statistics of the stratum corneum hydration, TEWL in infants and rate of changes in the score at each time point are calculated and compared between groups. Subgroup analysis is performed to assess the amount and frequency of moisturizer used in infants during the study. In addition, an exploratory investigation is performed to evaluate the skin images.

\section{TARC level}

Descriptive statistics of the serum TARC level at each time point are calculated and compared between groups. Subgroup analysis is performed to assess the incidence of infantile $\mathrm{AD}$ and eczema infantile, and the amount and frequency of moisturizer used during the study.

\section{Frequency of use and amount of moisturizer}

Descriptive statistics of the total amount of moisturizer and rate of changes in the scores at each time point are calculated and compared between groups. An evaluation is performed considering birth month as a baseline characteristic.

\section{Questionnaire survey on living habits, awareness, and knowledge of mothers before and after pregnancy}

Descriptive statistics of a questionnaire survey's scores at each time point are calculated and compared between groups. Changes in the self-evaluation at each time point and the related factors are compared between groups.

\section{Interim analysis}

No interim analysis will be conducted.

\section{Data collection procedure}

All data will be analyzed by members specifically trained in the study protocol in our hospital.

\section{Dissemination \\ Research ethics approval}

The study will be performed according to the Declaration of Helsinki (adopted by the 18th World Medical Association General Assembly, 1964, including subsequent revisions) and the Ethical Guidelines for Medical and Health Research Involving Human Subjects (Public Notice of the Ministry of Education, Culture, Sports, Science and Technology, and Ministry of Health, Labour and Welfare No. 3 of December, 2014). This study was approved by our hospital ethics committee. 


\section{Protocol amendments}

Any amendments to the protocol will be submitted to the Ethics Committee of Chiba Aiyu-kai Kinen Hospital for approval. Once approved, they will be reported to all the study investigators and, when necessary, to the study participants.

\section{Confidentiality}

All personnel involved in this study will comply with the applicable laws and regulations regarding confidentiality. Study personnel must make every effort to protect confidential information on the subjects and must not disclose the information obtained during the study to any third party without due cause. This is binding for any personnel even after they are no longer directly associated with the study. The investigator, the person in charge of the study, and study collaborators will use subject identification codes or registration numbers to enroll subjects and prepare case report forms instead of personal information that could be identified by a third party such as name, initials, address, telephone number, or medical chart number. With respect to information disclosure, the investigator or other personnel must carefully handle study data on the subjects to ensure that the data are not disclosed.

\section{Research funding and conflicts of interest}

The authors declare no conflicts of interest related to the plan, implementation, and reporting of the study results and interpretation of the results. The researchers independently planned, and will conduct, this study without funding or benefits from a company. Subjects do not lose any right or benefit by participating in this study.

\section{Safety of subjects and compensation related to participation in the study}

Subjects will need to allocate a certain amount of time to the study as follows: approximately $180 \mathrm{~min}$ for participation in sessions at 20 and 30 weeks of pregnancy, approximately $30 \mathrm{~min}$ for completing the questionnaire survey, and approximately 30 min for skin measurements at each time point. No special compensation is paid because adverse health effects are not expected, as the aim of the study is to educate subjects. However, if subjects experience any abnormal feelings during blood collection in the study, they must promptly contact the investigator to receive proper treatment.

\section{Dissemination policy}

The full protocol will be published in an academic journal in English. The study results will be announced to the public through presentations in academic meetings and publications in academic journals.

\section{Discussion}

Allergy is one of the most important health issues in developed countries. Allergies are common in many individuals worldwide, and can be present from babyhood through the person's lifetime. Many observational studies and RCTs have been performed to address the prevalence of allergies. These studies revealed that specific intervention strategies to prevent allergies are effective in some cases.

One of the strong points of this study is that it should provide pregnant women with accumulated information on preventive knowledge against allergy that can be effective in some cases, and the women can apply a combination of these behaviors before and after pregnancy. However, our trial has a few limitations. First, the trial may not provide clear data on the association between individual preventive measures and risk factors for allergy because the mothers themselves will be responsible for selecting and applying a combination of preventive measures. The second limitation is the study population because our sample is a relatively homogeneous group of pregnant women who are giving birth in a single hospital. Therefore, our findings may not be generalizable to other institutions or communities. However, at least in present-day Japan, a system for pregnant women to receive education is already in place, so we hope that all hospitals will have the opportunity to conduct our educational program.

Currently, most pregnant women in Japan are concerned about the potential development of allergies in their babies. If the results of the study indicate that the educational program has a positive effect on preventing allergies, "prenatal education to prevent allergy in infants" should be added to the existing childbirth educational program provided by medical institutions and local governments or the physician's instructions provided during infant examinations. This may decrease the anxiety of pregnant women and prevent allergy in infants. Our educational program is based on research findings from papers published in international medical journals. Thus, this program, which is the first study to determine the effect of education on allergy prevention, is expected to be effective both within and outside the Japanese population. The results of our program will be publicized to help change the behaviors of mothers and, if the program is effective for preventing allergies in infants, it will be disclosed worldwide as a new preventive approach for allergy in infants.

\section{Trial status}

Participant recruitment started in May 2019 and is scheduled to end in April 2020. This report is based on protocol version 9 . 


\section{Appendix}

Table $\mathbf{3}$ Self-evaluation of questionnaire at 4 months after delivery

\begin{tabular}{|c|c|c|c|c|c|}
\hline Question & Options & & & & \\
\hline $\begin{array}{l}\text { How often do you vacuum } \\
\text { the bed pad? }\end{array}$ & Never & Once a month & Once a week & 2 or 3 times a week & Every day \\
\hline $\begin{array}{l}\text { How often do you wash } \\
\text { the bedclothes? }\end{array}$ & Never & Once a month & Once a week & 2 or 3 times a week & Every day \\
\hline $\begin{array}{l}\text { Are there any smokers } \\
\text { living together? } \\
\text { If yes, where do they smoke? }\end{array}$ & $\begin{array}{l}\text { Yes } \\
\text { Any place }\end{array}$ & $\begin{array}{l}\text { Yes } \\
\text { Under a ventilator }\end{array}$ & $\begin{array}{l}\text { Yes } \\
\text { Only outside the room }\end{array}$ & $\begin{array}{l}\text { Yes } \\
\text { Only outside the home }\end{array}$ & No one at all \\
\hline $\begin{array}{l}\text { Do you smoke? } \\
\text { If yes, how often do you smoke? }\end{array}$ & $\begin{array}{l}\text { Yes } \\
\text { Frequently }\end{array}$ & $\begin{array}{l}\text { Yes } \\
\text { Often }\end{array}$ & $\begin{array}{l}\text { Yes } \\
\text { Sometimes }\end{array}$ & $\begin{array}{l}\text { No } \\
\text { But used to smoke }\end{array}$ & $\begin{array}{l}\text { No } \\
\text { Never smoked }\end{array}$ \\
\hline $\begin{array}{l}\text { How long are you be } \\
\text { exposed to sunlight? }\end{array}$ & Not at all & $\begin{array}{l}\text { Less than } 30 \mathrm{~min} \\
\text { a day }\end{array}$ & 30 min to $1 \mathrm{~h}$ a day & 1 to $2 \mathrm{~h}$ a day & $2 \mathrm{~h}$ or more a day \\
\hline How often do you use sunscreen? & Never & Rarely & Sometimes & Everyday & 2 times a day \\
\hline $\begin{array}{l}\text { How often do you take } \\
\text { your baby outside? }\end{array}$ & Never & As long as possible & As short as possible & Not conscious & $\begin{array}{l}\text { Short time with } \\
\text { conscious }\end{array}$ \\
\hline How often do you eat fish? & $\begin{array}{l}\text { Less than once } \\
\text { a week }\end{array}$ & 1 or 2 times a week & 3 or 4 times a week & 5 or 6 times a week & Every day \\
\hline How often do you eat eggs? & $\begin{array}{l}\text { Less than once } \\
\text { a week }\end{array}$ & 1 or 2 times a week & 3 or 4 times a week & 5 or 6 times a week & Every day \\
\hline How often do you eat meat? & $\begin{array}{l}\text { Less than once } \\
\text { a week }\end{array}$ & 1 or 2 times a week & 3 or 4 times a week & 5 or 6 times a week & Every day \\
\hline How often do you eat mushrooms? & $\begin{array}{l}\text { Less than once } \\
\text { a week }\end{array}$ & 1 or 2 times a week & 3 or 4 times a week & 5 or 6 times a week & Every day \\
\hline $\begin{array}{l}\text { How often do you eat foods } \\
\text { containing Lactobacillus? }\end{array}$ & $\begin{array}{l}\text { Less than once } \\
\text { a week }\end{array}$ & 1 or 2 times a week & 3 or 4 times a week & 5 or 6 times a week & Every day \\
\hline How often do you eat seaweeds? & $\begin{array}{l}\text { Less than once } \\
\text { a week }\end{array}$ & 1 or 2 times a week & 3 or 4 times a week & 5 or 6 times a week & Every day \\
\hline $\begin{array}{l}\text { How often do you use soap } \\
\text { when bathing your baby? }\end{array}$ & $\begin{array}{l}\text { Less than once } \\
\text { a week }\end{array}$ & 1 or 2 times a week & 3 or 4 times a week & 5 or 6 times a week & Every day \\
\hline $\begin{array}{l}\text { How often do you wash your } \\
\text { baby with a lathered soap? }\end{array}$ & Never & Rarely & Sometimes & Frequently & Always \\
\hline $\begin{array}{l}\text { How do you wash your } \\
\text { baby's face? }\end{array}$ & With hot water & Wear with gauze & $\begin{array}{l}\text { Only cheeks or round } \\
\text { mouth with soap }\end{array}$ & $\begin{array}{l}\text { Whole face with } \\
\text { soap but avoiding } \\
\text { eyes }\end{array}$ & Whole face with soap \\
\hline $\begin{array}{l}\text { How do you wash your } \\
\text { baby's body? }\end{array}$ & Not at all & With hot water & Wear with gauze & $\begin{array}{l}\text { Whole body with } \\
\text { soap but avoiding } \\
\text { eyes }\end{array}$ & Whole body with soap \\
\hline $\begin{array}{l}\text { How often do you use } \\
\text { moisturizer for your baby? }\end{array}$ & Never & Rarely & $\begin{array}{l}\text { Serious skin } \\
\text { problems occur }\end{array}$ & $\begin{array}{l}\text { Any skin problems } \\
\text { occur }\end{array}$ & Every day \\
\hline $\begin{array}{l}\text { How much moisturizer do } \\
\text { you use for your baby? }\end{array}$ & Not at all & Rubbing & Thinly & $\begin{array}{l}\text { Thinly or plenty } \\
\text { depend on body part }\end{array}$ & Plenty \\
\hline $\begin{array}{l}\text { How often do you use } \\
\text { moisturizer for your baby? }\end{array}$ & Never & Rarely & Once a day if possible & Once a day at least & $\begin{array}{l}\text { More than } 2 \text { times } \\
\text { a day }\end{array}$ \\
\hline $\begin{array}{l}\text { Which part of your baby } \\
\text { do you use moisturizer? }\end{array}$ & Not at all & Arms and legs & Only face & Only body & $\begin{array}{l}\text { Face and whole } \\
\text { body }\end{array}$ \\
\hline
\end{tabular}

Please select the one that best fits your current situation 


\section{Supplementary information}

Supplementary information accompanies this paper at https://doi.org/10. 1186/s13063-019-3797-2.

Additional file 1. Standard Protocol Items: Recommendations for Interventional Trial (SPIRIT) 2013 Checklist: recommended items to address in a clinical trial protocol and related documents.

Additional file 2. Consent, enrolment/allocation, and assessment of subjects according to SPRIT format.

\section{Abbreviations}

AD: Atopic dermatitis; Cl: Confidence interval; FA: Food allergy; PAE: Pediatric allergy educator; RCT: Randomized controlled trial; SCORAD: Scoring atopic dermatitis; TARC: Thymus and activation-regulated chemokine; UMINCTR: University Hospital Medical Information Network - Clinical Trials Registry; VD: Vitamin D

\section{Acknowledgements}

We would like to express our deep gratitude to Associate Professor Hisashi Noma, Department of Data Science, The Institute of Statistical Mathematics, for his support and cooperation.

\section{Authors' contributions}

YN and $\mathrm{NI}$ conceived of the study. RN wrote the first draft of the manuscript. All authors designed the study, and contributed to, read, and approved version of this manuscript.

\section{Funding}

This trial is conducted with no external funding and is instead from internal funding.

\section{Availability of data and materials}

Data sharing is not applicable to this article as no datasets were generated or analyzed during the current study.

\section{Ethics approval and consent to participate}

The study will be performed according to the Declaration of Helsinki (adopted by the 18th World Medical Association General Assembly, 1964, including subsequent revisions) and the Ethical Guidelines for Medical and Health Research Involving Human Subjects (Public Notice of the Ministry of Education, Culture, Sports, Science and Technology, and Ministry of Health, Labour and Welfare No. 3 of December, 2014). The study protocol was reviewed and approved by the Ethics Committee of Chiba Aiyu-kai Kinen Hospital. All participants will provide written informed consent prior to participation.

\section{Consent for publication}

This item is not applicable.

\section{Competing interests}

The authors declare that they have no competing interests.

\section{Author details}

${ }^{1}$ KOSÉ Corporation Research Laboratories, 48-18 Sakae-cho, Kita-ku, Tokyo 114-0005, Japan. ${ }^{2}$ Chiba Aiyu-kai Kinen hospital, 1-1 Niregasaki,

Nagareyama-shi, Chiba 270-0161, Japan.

Received: 2 May 2019 Accepted: 11 October 2019

Published online: 21 December 2019

\section{References}

1. Asher MI, Montefort S, Björkstén B, et al. Worldwide time trends in the prevalence of symptoms of asthma, allergic rhinoconjunctivitis, and eczema in childhood: ISAAC Phases One and Three repeat multicountry crosssectional surveys. Lancet. 2006;368(9537):733-43. https://doi.org/10.1016/ S0140-6736(06)69283-0.
2. Dharmage SC, Lowe AJ, Matheson MC, et al. Atopic dermatitis and the atopic march revisited. Allergy. 2014;69(1):17-27. https://doi.org/10.1111/all. 12268 [published Online First: 14 Oct 2013].

3. Hill DA, Spergel JM. The atopic march: critical evidence and clinical relevance. Ann Allergy Asthma Immunol. 2018;120(2):131-7. https://doi.org/ 10.1016/j.anai.2017.10.037 [published Online First: 8 Feb 2018].

4. Lack G. Epidemiologic risks for food allergy. J Allergy Clin Immunol. 2008; 121(6):1331-6. https://doi.org/10.1016/j.jaci.2008.04.032.

5. Lack G. Update on risk factors for food allergy. J Allergy Clin Immunol. 2012; 129(5):1187-97. https://doi.org/10.1016/j.jaci.2012.02.036 [published Online First: 30 Mar 2012]

6. Horimukai K, Morita K, Narita M, et al. Application of moisturizer to neonates prevents development of atopic dermatitis. J Allergy Clin Immunol. 2014; 134(4):824-30.e6. doi: [published Online First: 6 Oct 2014]. https://doi.org/10. 1016/j.jaci.2014.07.060

7. Simpson EL, Chalmers JR, Hanifin JM, et al. Emollient enhancement of the skin barrier from birth offers effective atopic dermatitis prevention. J Allergy Clin Immunol. 2014;134(4):818-23. https://doi.org/10.1016/j.jaci.2014.08.005 [published Online First: 6 Oct 2014].

8. Lowe AJ, Leung DYM, Tang MLK, et al. The skin as a target for prevention of the atopic march. Ann Allergy Asthma Immunol. 2018;120(2):145-51. https://doi.org/10.1016/j.anai.2017.11.023.

9. Lowe AJ, Su JC, Allen KJ, et al. A randomized trial of a barrier lipid replacement strategy for the prevention of atopic dermatitis and allergic sensitization: the PEBBLES pilot study. Br J Dermatol. 2018;178(1):e19-21. https://doi.org/10.1111/bjd.15747 [published Online First: 24 Jun 2017].

10. Abrahamsson TR, Wu RY, Jenmalm MC. Gut microbiota and allergy: the importance of the pregnancy period. Pediatr Res. 2015;77(1-2):214-9. https://doi.org/10.1038/pr.2014.165 [published Online First: 14 Oct 2014].

11. Vuillermin PJ, Macia L, Nanan R, et al. The maternal microbiome during pregnancy and allergic disease in the offspring. Semin Immunopathol. 2017; 39(6):669-75. https://doi.org/10.1007/s00281-017-0652-y [published Online First: 19 Oct 2017]

12. Fiocchi A, Pawankar R, Cuello-Garcia C, et al. World Allergy OrganizationMcMaster University Guidelines for Allergic Disease Prevention (GLAD-P): Probiotics. World Allergy Organ J. 2015;8(1):4. https://doi.org/10.1186/ s40413-015-0055-2 [published Online First: 30 Jan 2015].

13. Cuello-Garcia CA, Fiocchi A, Pawankar R, et al. World Allergy OrganizationMcMaster University Guidelines for Allergic Disease Prevention (GLAD-P): Prebiotics. World Allergy Organ J. 2016;9:10. https://doi.org/10.1186/s40413016-0102-7 [published Online First: 11 Mar 2016].

14. Barengolts E. Gut microbiota, prebiotics, probiotics, and synbiotics in management of obesity and prediabetes: review of randomized controlled trials. Endocr Pract. 2016;22(10):1224-34. https://doi.org/10.4158/ep151157.ra [published Online First: 14 Jul 2016].

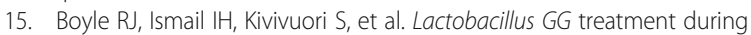
pregnancy for the prevention of eczema: a randomized controlled trial. Allergy. 2011;66(4):509-16. https://doi.org/10.1111/j.1398-9995.2010.02507.x [published Online First: 3 Dec 2010].

16. Huurre A, Laitinen K, Rautava S, et al. Impact of maternal atopy and probiotic supplementation during pregnancy on infant sensitization: a double-blind placebo-controlled study. Clin Exp Allergy. 2008;38(8):1342-8. https://doi.org/10. 1111/j.1365-2222.2008.03008xx [published Online First: 15 May 2008].

17. Dotterud CK, Storro O, Johnsen R, et al. Probiotics in pregnant women to prevent allergic disease: a randomized, double-blind trial. Br J Dermatol. 2010;163(3):616-23. https://doi.org/10.1111/j.1365-2133.2010.09889.x [published Online First: 16 Jun 2010].

18. Rautava S, Kainonen E, Salminen S, et al. Maternal probiotic supplementation during pregnancy and breast-feeding reduces the risk of eczema in the infant. J Allergy Clin Immunol. 2012;130(6):1355-60. https:// doi.org/10.1016/j.jaci.2012.09.003 [published Online First: 23 Oct 2012].

19. Rautava S, Kalliomaki M, Isolauri E. Probiotics during pregnancy and breastfeeding might confer immunomodulatory protection against atopic disease in the infant. J Allergy Clin Immunol. 2002;109(1):119-21 [published Online First: 19 Jan 2002]

20. Zuccotti G, Meneghin F, Aceti A, et al. Probiotics for prevention of atopic diseases in infants: systematic review and meta-analysis. Allergy. 2015;70(11): 1356-71. https://doi.org/10.1111/all.12700 [published Online First: 23 Jul 2015].

21. Cuello-Garcia CA, Brozek JL, Fiocchi A, et al. Probiotics for the prevention of allergy: a systematic review and meta-analysis of randomized controlled 
trials. J Allergy Clin Immunol. 2015;136(4):952-61. https://doi.org/10.1016/j. jaci.2015.04.031 [published Online First: 6 Jun 2015].

22. Cuello-Garcia C, Fiocchi A, Pawankar R, et al. Prebiotics for the prevention of allergies: a systematic review and meta-analysis of randomized controlled trials. Clin Exp Allergy. 2017;47(11):1468-77. https://doi.org/10.1111/cea. 13042 [published Online First: 17 Oct 2017].

23. Chang YS, Trivedi MK, Jha A, et al. Synbiotics for prevention and treatment of atopic dermatitis: a meta-analysis of randomized clinical trials. JAMA Pediatr. 2016;170(3):236-42. https://doi.org/10.1001/jamapediatrics.2015.3943 [published Online First: 27 Jan 2016].

24. Sasaki M, Yoshida K, Adachi Y, et al. Environmental factors associated with childhood eczema: findings from a national web-based survey. Allergol Int. 2016;65(4):420-4. https://doi.org/10.1016/j.alit.2016.03.007 [published Online First: 3 May 2016].

25. Leas BF, D'Anci KE, Apter AJ, et al. Effectiveness of indoor allergen reduction in asthma management: a systematic review. J Allergy Clin Immunol. 2018; 141(5):1854-69. https://doi.org/10.1016/j.jaci.2018.02.001 [published Online First: 17 Feb 2018].

26. Burke H, Leonardi-Bee J, Hashim A, et al. Prenatal and passive smoke exposure and incidence of asthma and wheeze: systematic review and meta-analysis. Pediatrics. 2012;129(4):735-44. https://doi.org/10.1542/peds. 2011-2196 [published Online First: 21 Mar 2012].

27. Silvestri M, Franchi S, Pistorio A, et al. Smoke exposure, wheezing, and asthma development: a systematic review and meta-analysis in unselected birth cohorts. Pediatr Pulmonol. 2015;50(4):353-62. https://doi.org/10.1002/ ppul.23037 [published Online First: 22 Mar 2014].

28. Vardavas $\mathrm{Cl}$, Hohmann $\mathrm{C}$, Patelarou $\mathrm{E}$, et al. The independent role of prenatal and postnatal exposure to active and passive smoking on the development of early wheeze in children. Eur Respir J. 2016:48(1):115-24. https://doi.org/10. 1183/13993003.01016-2015 [published Online First: 12 Mar 2016].

29. Devereux G, Litonjua AA, Turner SW, et al. Maternal vitamin D intake during pregnancy and early childhood wheezing. Am J Clin Nutr. 2007;85(3):853-9. https://doi.org/10.1093/ajcn/85.3.853 [published Online First: 9 Mar 2007].

30. Pacheco-Gonzalez RM, Garcia-Marcos L, Morales E. Prenatal vitamin D status and respiratory and allergic outcomes in childhood: a meta-analysis of observational studies. Pediatr Allergy Immunol. 2018;29(3):243-53. https:// doi.org/10.1111/pai.12876 [published Online First: 15 Feb 2018].

31. Chawes BL, Bonnelykke K, Jensen PF, et al. Cord blood 25(OH)-vitamin D deficiency and childhood asthma, allergy and eczema: the COPSAC2000 birth cohort study. PLoS One. 2014;9(6):e99856. https://doi.org/10.1371/ journal.pone.0099856 [published Online First: 14 Jun 2014].

32. Maslova E, Strom M, Oken E, et al. Fish intake during pregnancy and the risk of child asthma and allergic rhinitis - longitudinal evidence from the Danish National Birth Cohort. Br J Nutr. 2013;110(7):1313-25. https://doi.org/10. 1017/s000711451300038x [published Online First: 12 Mar 2013].

33. Miyake Y, Sasaki S, Tanaka K, et al. Fish and fat intake and prevalence of allergic rhinitis in Japanese females: the Osaka Maternal and Child Health Study. J Am Coll Nutr. 2007;26(3):279-87 [published Online First: 20 Jul 2007].

34. Gunaratne AW, Makrides M, Collins CT. Maternal prenatal and/or postnatal n-3 long chain polyunsaturated fatty acids (LCPUFA) supplementation for preventing allergies in early childhood. Cochrane Database Syst Rev. 2015; (7):Cd010085. https://doi.org/10.1002/14651858.CD010085.pub2 [published Online First: 22 Jul 2015].

35. Perez-Lopez FR, Pasupuleti V, Mezones-Holguin E, et al. Effect of vitamin D supplementation during pregnancy on maternal and neonatal outcomes: a systematic review and meta-analysis of randomized controlled trials. Fertil Steril. 2015;103(5):1278-88.e4. [published Online First: 31 Mar 2015]. https:// doi.org/10.1016/j.fertnstert.2015.02.019.

36. Wei Z, Zhang J, Yu X. Maternal vitamin D status and childhood asthma, wheeze, and eczema: a systematic review and meta-analysis. Pediatr Allergy Immunol. 2016;27(6):612-9. https://doi.org/10.1111/pai.12593 [published Online First: 5 May 2016].

37. Yepes-Nunez JJ, Brozek JL, Fiocchi A, et al. Vitamin D supplementation in primary allergy prevention: Systematic review of randomized and nonrandomized studies. Allergy. 2018;73(1):37-49. https://doi.org/10.1111/all. 13241 [published Online First: 5 Jul 2017].

38. Roth $D E$, Leung $M$, Mesfin $E$, et al. Vitamin $D$ supplementation during pregnancy: state of the evidence from a systematic review of randomised trials. BMJ. 2017;359:j5237. https://doi.org/10.1136/bmj.j5237 [published Online First: 1 Dec 2017].
39. Beckhaus AA, Garcia-Marcos L, Forno E, et al. Maternal nutrition during pregnancy and risk of asthma, wheeze, and atopic diseases during childhood: a systematic review and meta-analysis. Allergy. 2015;70(12):1588604. https://doi.org/10.1111/all.12729 [published Online First: 25 Aug 2015].

40. Best KP, Gold M, Kennedy D, et al. Omega-3 long-chain PUFA intake during pregnancy and allergic disease outcomes in the offspring: a systematic review and meta-analysis of observational studies and randomized controlled trials. Am J Clin Nutr. 2016;103(1):128-43. https://doi.org/10.3945/ ajcn.115.111104 [published Online First: 18 Dec 2015].

41. Goldring ST, Griffiths CJ, Martineau AR, et al. Prenatal vitamin d supplementation and child respiratory health: a randomised controlled trial. PLoS One. 2013;8(6):e66627. https://doi.org/10.1371/journal.pone.0066627 [published Online First: 5 Jul 2013].

42. Litonjua AA, Carey VJ, Laranjo N, et al. Effect of prenatal supplementation with vitamin $D$ on asthma or recurrent wheezing in offspring by age 3 years: the VDAART randomized clinical trial. JAMA. 2016;315(4):362-70. https://doi.org/10. 1001/jama.2015.18589 [published Online First: 28 Jan 2016].

43. Wolsk HM, Chawes BL, Litonjua AA, et al. Prenatal vitamin D supplementation reduces risk of asthma/recurrent wheeze in early childhood: a combined analysis of two randomized controlled trials. PLoS One. 2017;12(10):e0186657. https://doi.org/10.1371/journal.pone.0186657 [published Online First: 28 Oct 2017].

44. Wolsk HM, Harshfield BJ, Laranjo N, et al. Vitamin D supplementation in pregnancy, prenatal $25(\mathrm{OH}) \mathrm{D}$ levels, race, and subsequent asthma or recurrent wheeze in offspring: Secondary analyses from the Vitamin D Antenatal Asthma Reduction Trial. J Allergy Clin Immunol. 2017;140(5):1423-9.e5. [published Online First: 14 Mar 2017]. https:/doi.org/10.1016/j.jaci.2017.01.013.

45. Palmer DJ, Sullivan T, Gold MS, et al. Effect of $n-3$ long chain polyunsaturated fatty acid supplementation in pregnancy on infants' allergies in first year of life: randomised controlled trial. BMJ. 2012;344:e184. https://doi.org/10.1136/bmj.e184 [published Online First: 2 Feb 2012].

46. Dunstan JA, Mori TA, Barden A, et al. Fish oil supplementation in pregnancy modifies neonatal allergen-specific immune responses and clinical outcomes in infants at high risk of atopy: a randomized, controlled trial. J Allergy Clin Immunol. 2003;112(6):1178-84. https://doi.org/10.1016/j.jaci. 2003.09.009 [published Online First: 6 Dec 2003].

47. Suzuki T, et al. Current status of neonatal skin care by mothers of newborns who underwent a one-month medical examination. J Pediat Dermatol. 2014;33(1):7-12.

48. Hoffmann TC, Glasziou PP, Boutron I, et al. Better reporting of interventions: Template for Intervention Description and Replication (TIDieR) Checklist and guide. BMJ. 2014;348:g1687. https://doi.org/10.1136/bmj.g1687 [published Online First: 13 Mar 2014].

49. Suzuki K, Hiyoshi M, Tada H, et al. Allergen diagnosis microarray with highdensity immobilization capacity using diamond-like carbon-coated chips for profiling allergen-specific IgE and other immunoglobulins. Anal Chim Acta. 2011;706(2):321-7. https://doi.org/10.1016/j.aca.2011.08.034 [published Online First: 26 Oct 2011$]$.

50. Severity scoring of atopic dermatitis: the SCORAD index. Consensus Report of the European Task Force on Atopic Dermatitis. Dermatology. 1993;186(1):2331. https://doi.org/10.1159/000247298 [published Online First: 1 Jan 1993].

51. Mallinckrodt CH, Clark WS, David SR. Accounting for dropout bias using mixed-effects models. J Biopharm Stat. 2001;11(1-2):9-21. https://doi.org/10. 1081/bip-100104194 [published Online First: 19 Jul 2001].

\section{Publisher's Note}

Springer Nature remains neutral with regard to jurisdictional claims in published maps and institutional affiliations. 